\title{
Corrigendum: Nuclear RNA-seq of single neurons reveals molecular signatures of activation
}

Benjamin Lacar, Sara B. Linker, Baptiste N. Jaeger, Suguna Rani Krishnaswami, Jerika J. Barron, Martijn J.E. Kelder, Sarah L. Parylak, Apuã C.M. Paquola, Pratap Venepally, Mark Novotny, Carolyn O'Connor, Conor Fitzpatrick, Jennifer A. Erwin, Jonathan Y. Hsu, David Husband, Michael J. McConnell, Roger Lasken \& Fred H. Gage

Nature Communications 7:11022 doi: 10.1038/ncomms11022 (2016); Published 19 Apr 2016; Updated 14 Jun 2016

In the original version of this Article, the middle names or initials of the authors Suguna Rani Krishnaswami, Jerika J. Barron, Martijn J.E. Kelder, Sarah L. Parylak, Apuã C.M. Paquola and Jennifer A. Erwin were omitted from the author information. In addition, financial support for Benjamin Lacar from the UCSD Temporal Dynamics of Learning Center was not acknowledged. These errors have now been corrected in both the PDF and HTML versions of the Article. article's Creative Commons license, unless indicated otherwise in the credit line; if the material is not included under the Creative Commons license, users will need to obtain permission from the license holder to reproduce the material. To view a copy of this license, visit http://creativecommons.org/licenses/by/4.0/
} 